\title{
Socio-Cultural Impact in Tourism: A Case Study of Sauraha, Nepal
}

\section{Janardan Poudel}

${ }^{1} \mathrm{Ph} . \mathrm{D}$ Scholar, Mewar University

Gangrar, Chittorgar, Rajasthan, India

\begin{abstract}
Locaton: Sauraha is $166 \mathrm{~km}$. south west from Kathmandu. It is situated at an altitude of $150 \mathrm{~m}$ (492 feet) form the sea level. Its shape is rectangular and speared with east west direction. It is in close proximity with the Chitwan National Park, Tandi and Chitrasari being at a distance of 6 and $3 \mathrm{~km}$. respectively from it. However, Tandi, the entry point to Sauraha, is situated on the east west highway, $20 \mathrm{~km}$. from the main city of Bharatpur. Objective: The objective of the study is to study the socio cultural impact in Tharus' culture, customs, tradition and lifestyle by tourism. Methodology: Observation and questionnaire method will be used as data collection tools. This research will adopt descriptive research design. Descriptive in a sense: the research will carefully try to record all the observed events from the study area and describes fairly as possible. Result: Local people have changed their life style, their traditional values, cultural aspects and are following the borrowed values and aspects in the name of modernization. Conclusion: Sauraha, is the best location for the tourism industry. It is a part of Bachhauly VDC. It is worldwidely famous for its ethnic and cultural diversity. Numbers of tourists have come to visit the Chitwan National Park and most of the tourists go to Sauraha to stay and to study the cultural and traditional aspects of the Tharus. The cultural assimilation occurs when two cultures come in contact. The more technologically influential group gains supremacy while the latter society readily adopts the former's way of living. The same phenomenon can be observed in Sauraha, where the host culture is highly influenced and affected by the guest culture.
\end{abstract}

KEY WORDS: Sauraha, Socio-cultural impact, Tharus, Tourism

\section{INTRODUCTION}

Tourism is a human activity which has been proved important for all nations since it fosters international brotherhood and understanding. With the passage of time, and increasing affluence, tourism is becoming more popular as well as important throughout the world.

Tourism is the world's fastest growing industry. Nepal is the country of Mount Everest similarly national as well as manmade heritages are famous and popular all over the world. Various places of Nepal are listed in the world heritage site. Hospitality, friendly people, numerous attractions, unique cultures are the main tourist attractions in the country. In Nepal tourists flow had been seen highest in the years of 1998 and 1999 but since 2002, the flow of tourist was decreasing. In this care, numerous factors are responsible, such as conflict, political instability, lack of marketing, regional unhealthy competition, adverse propagandas and so on. However, tourism is the bread and butter of Nepalese people. The future of the country depends mainly on the tourism industry's development. Nepal is a rural country because majority of the people reside in the rural areas thus tourism is the most feasible sector for the development of the country. This can be stated by considering the present tourism scenario and that various programmes have been launching for the promotion of tourism in the country. Tourism itself has been providing job opportunities directly and indirectly and at the same time tourism has also been initiating to 
protect natural and cultural heritages. It is responsible for about 24 percent of the total foreign currency income of the nation. It contributes 4 percent GDP. (Himalayan times, 2003)

Tourism is the total relationship and phenomena linked with the stay of foreign persons to a locality on condition that they do not settle there to exercise a major permanent or temporary activity of a lucrative nature.

The curiosity about why do people travel is a matter of concern in tourism study. People travel for various reasons and purposes. Tourism can be classified on the basis of several factors such as geographical location, purpose of visit, the number of persons traveling etc. The basic distinction in tourism is viewed between domestic and international tourism.

"Tourism is the temporary movement of people to the destinations outside their normal places of work and residence, the activities undertaken during their stay in those destinations, and the facilities created to cater to their needs" (Mathieson \& Wall, 1982, p.1). During their stay in the destination, tourists interact with local residents and the outcome of their relationship changes the host individuals' and host community's quality of life, value systems, labour division, family relationships, attitudes, behavioural patterns, ceremonies and creative expressions (Fox, 1977; Cohen, 1984; Pizam \& Milman, 1984).

Tourism is a genuinely powerful and unique force for change in community (Kunwar, 2006). It has several impacts in society as well as culture of the host country. King Mahendra Trust for Nature Conservation (KMTNC) had published a report in 1996 and it had focused on the visitor's duration of stay, accommodation, food, tourist facilities, guide services, travel cost have been put forwarded but it is silent to draw the impacts of tourism on Tharu community.

The objective of the study is to study the socio cultural impact in Tharu culture, customs, and tradition and lifestyle by tourism.

\section{Study Area}

Chitwan is one of the five districts (Chitwan, Gaur, Parsa, Makawanpur, Rauthahat) of Narayani zone in the middle development region of Nepal. The geographical location of Chitwan district is $83^{0} 55^{\prime} 45^{\prime \prime}$ east to $84^{0} 48^{\prime} 15^{\prime \prime}$ east longitude and $27^{0} 52^{\prime} 36^{\prime \prime}$ north to $27^{0} 46^{\prime}$ north latitude.

It is located in the middle part of Nepal. Chitwan has tropical and sub-tropical monsoon climate with high humidity and three main seasons: summer, monsoon and winter. It is endowed with rich basins and valleys. The valley consists of outer most series of low-elevation hills and mountains of the Himalayas and the Mosaic of riverine forest grass lands and sub-tropical saal (Shorea robusta) forest supporting a wide diversity and native flora and fauna including endangered animals and wildlife species. Chitwan valley is uniquely endowed with rich natural cultural and religious heritages. Chitwan covers 2,519 square kilometer or 1.51 percent of total area of Nepal.

Chitwan has numerous Tourist destinations. In the perspective of Religion, Culture, Archeology and Nature, Chitwan is a significant place. In the view of Transportation, Communication and Distance from the capital, it is easily accessible. (Upadhaya, Rudra, 2008)

Cultural diversity is a strong significant feature of Chitwan. Many temples of Hindus and Gombas of Budhist are located in Chitwan. Devghat Dham, Sita Gunpha, Panchpandav, Bikram Baba Temple, Balmiki Ashram, Brahma Chauri and Laxmi Narayan Temple, Godak Nath Temple and several holy ponds have religious and historical significance.

Chitwan National Park (CNP) is one of the important destinations of tourism in Nepal which is next to Sauraha. The popularity of this protected region of Nepal is rapidly increasing since its establishment. Only 836 visitors were found to have visited CNP in 1974 where as this 
figure increased up to 86443 in 2007 , a hundred times increase in the period of 3 decades. Among them at least 50\% had visited Sauraha. This reveals that tourism activities have been increased day by day at Sauraha and at the CNP.

Bacchauli VDC is situated in the east part of Chitwan which occupies $23.94 \mathrm{sq} . \mathrm{km}$. area of the district. It is surrounded by Padampur to the south, Kumroj and Khairani to the east, Ratnanagar to the north and the Chitwan National Park to the west.

It is one of the agriculturally diversified areas of Chitwan district consisting of different community forests, rich in different biodiversity. Sauraha, is the best location for the tourism industry. It is a part of Bachhauly VDC. It is worldwide famous for its ethnic diversity. Numbers of tourists come to visit the Chitwan National Park and most of them go to Sauraha for the night stay and to study the cultural and traditional aspects of the Tharu community.

Statistical data of the tourist arrival in Nepal and CNP

Table No. 1 of Tourists Arrival in Nepal and CNP

\begin{tabular}{|l|l|l|l|}
\hline Year & Total numbers & Share of arrival in CNP & Percentage \% \\
\hline 2001 & 361237 & 82542 & 22.85 \\
\hline 2002 & 275468 & 46705 & 16.955 \\
\hline 2003 & 338132 & 56303 & 16.651 \\
\hline 2004 & 385297 & 43061 & 11.176 \\
\hline 2005 & 375398 & 52572 & 14.004 \\
\hline 2006 & 383926 & 60126 & 15.661 \\
\hline 2007 & 526705 & 86443 & 16.412 \\
\hline 2008 & 500277 & 82723 & 16.535 \\
\hline 2009 & 509956 & 78682 & 15.429 \\
\hline 2010 & 602867 & 84518 & 14.019 \\
\hline 2011 & 736215 & 102332 & 13.899 \\
\hline 2012 & 803092 & 126484 & 15.749 \\
\hline
\end{tabular}

Source: Department of National Park and Wild life Conservation

From this statistical data, we can conclude that the number of tourists arriving has been increasing year by year. So, the impact on socio cultural context has not been decreasing. Most visitors make Sauraha, a nearby village of Chitwan National Park, their destination. Therefore, their appearance enhance to the effect on their socio cultural situation.

In Bacchauli VDC, there are altogether 5016 Tharus and the remaining population of 5427 is composed of Brahmans, Chhetris, Newars, Gurung, Magars, Kamis, Tamangs, Botes, Damais, Danuwars and Dhobis. Sauraha is located in and outside the national park. River Budhi Rapti has divided this VDC into two parts. Tandi Chitrasari and Gothauli are located on the Northern side of the river whereas Sauraha, Jhuwani, Malpur and Dadreni are in the southern side of the river. From tourism's point of view, Sauraha Dadreni and Odra village are very important because most of the resorts are located there. Moreover to the South of Sauraha there is a dense forest.

Sauraha is $166 \mathrm{~km}$. south west from Kathmandu. It is situated at an altitude of $150 \mathrm{~m} \mathrm{(492}$ feet) form the sea level. Its shape is rectangular and spread in east west direction. It is in close proximity with the Chitwan National Park, Tandi and Chitrasari being at a distance of 6 and 3 $\mathrm{km}$. respectively from it. However, Tandi, the entry point to Sauraha is situated on the east west highway, $20 \mathrm{~km}$. from the main city of Bharatpur. 


\section{Map of study area}

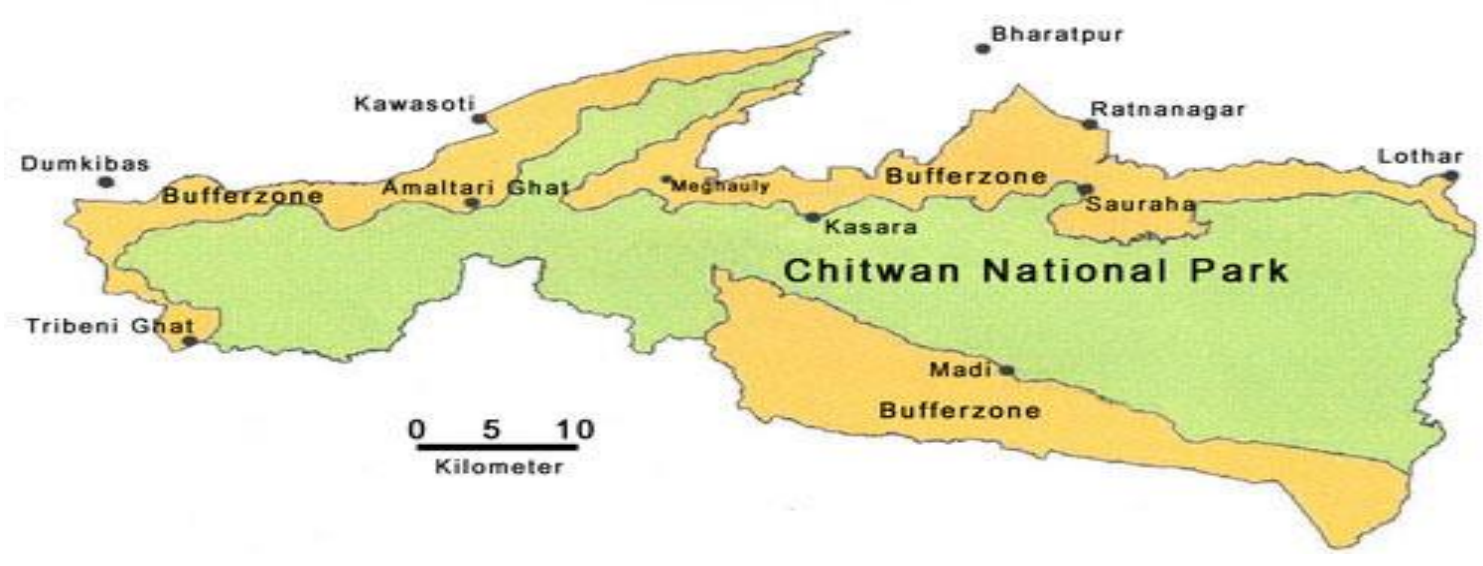

Source: maps.google.com/maps/ms

\section{Social Impacts}

\section{House Structure}

The Tharus have their own social system. It is found that the social structure of the natives have been changed drastically in recent days. Previously, each and every household of the Tharus were made of cow dung, strew, soil, bamboo etc. There used to be no windows in their houses. Besides, most hotels and resorts were also built in the traditional Tharu style in Chitwan. Gradually, the natives became attracted towards the modern style of construction. Apart from that, hotel owners, nowadays, have started to build their hotels and resorts in modern style where tourists are more secure than in the traditional houses of Tharus. Therefore, nowadays more than $60 \%$ natives, who are totally dependent in the tourism profession, have built their houses using modern technique, an idea that their parents oppose. So it can be said that the house owners who have built their houses in modern style belong to the elite group. It has also been found that the new generation wants to stay in concrete houses rather than traditional houses. They think that it is bad to live in an old house. They feel humiliated in front of the tourists due to lack of modernization. So, it is common that when the young generation is able to earn some money, they build their houses in a modern style.

\section{Family Structure}

Previously, Tharus used to have a largely extended joint family. It used to compose of more than three generations. But nowadays a dramatic change has occurred in the view of the natives, regarding the family structure. Most of the natives, especially the new generation are interested to stay in a nuclear family instead of a joint family due to their involvement in tourism profession directly or indirectly. They are not able to spend time in agriculture and other activities, a fact that can create quarrels between the members of the family. Besides, the natives have started to live in nuclear family on account of financial crisis. By objerving the lifestyle of the tourists, Tharus have become inclined towards the idea of nuclear family rather than traditional joint family. 


\section{Religion}

According to the respondents, the Tharu religion is concerned with supernatural forces. They have several deities associated with home, forest, and some different material cultures. Gana and Tripura are revered by every Tharu as home deities. The anthropomorphic deities are installed either inside or outside their houses. One of the major attributes of their religion is Baramthan, located outside the village. The Baramthan comprises of several deities. During festivals or celebrations, they worship their home deities and then go to the Baramthan. While worshipping the deities, they invite their priest known as "guruwa" and they worship God and Goddesses named Gana, Tripura, Bana Devi, Baramthan, Banjarahin etc.

Tharus had strong belief in their religion before the introduction of tourism in Sauraha. Actually, they were not so busy in the past. They used to spend a lot of time worshipping their deities but nowadays they don't have enough time to spend on all those processes because they are busy in their profession as room boys, gardeners, naturalists, hotel owners etc. It can be said that modernization and urbanization have motivated the local people to change their traditional beliefs.

They do not want to spend their valuable time celebrating traditional festivals. Previously, they used to celebrate their festivals with long process but nowadays they have started to observe the festivals in a short cut way.

Beside their own festivals, they also celebrate Dashain, Tihar, Christmas and other festivals belonging to the hill migrants and other groups. So, it can be said that tourism is responsible for bringing changes in their view of religion. In this way the Tharu culture was assimilated with dilute of foreign culture and non-Tharu culture.

\section{Moral Behavior}

\section{Crime and Gambling:}

Previously Tharus were busy in their business and they were innocent in their manner but later on when they got involved in the tourism profession they started to play ludo, snooker and started to get involved in gambling. Generally, they play cards during their leisure time.

\section{Prostitution:}

It is one of the various attractions of every tourist destination. Regarding this, there is no report about institutionalization of prostitution in the study area. The local people who were asked anything about prostitution at study area, majority of them disagreed. This is an evidence of awareness about their healthy society which is a positive impact of tourism.

\section{Drugs addiction:}

In most of the tourist destinations, young natives are found to be involved in drug activities. It is reported that generally free individual tourists (FIT) are involved in such activities. The guests seem very happy with the service providers from whom they get Hashish and provide them big amount of money as tips.

\section{Linguistic Acculturation:}

In Nepal there are about 61 ethnic castes groups and 70 dialects. Out of them, the Tharu speaks their own dialect. The Tharus of Chitwan have their own language called 'Magadhi'. It's 
very difficult for them to talk in English with the tourists so after introduction to tourism in Sauraha, involving people in tourism can communicate their ideas easily with tourist. A man who does not know the English alphabets cannot speak English fluently. As a result, majority of the youngsters of the Tharu community have forgotten their language and culture.

\section{Demonstration Effect:}

The traditional dresses of a Tharu male are Kachhad and Langauti where as a female wears Dhoti. In the process of urbanization and modernization non - Tharus started to migrate and tourism activities started to flourish in the area. After some times, Tharus started to discard their traditional attires. Most of the tourists visit the Tharu village with several modern belongings such as camera, watch, sunglasses, track suits etc. The natives are highly influenced by their belongings and now have started to copy foreigners' attires and lifestyle. It is seen that the new generation of the community has started to blindly accept the western lifestyle. Most of the respondents have accepted this reality as their progress. All the above facts show that traditional dresses of Tharus have gradually started to disappear.

Besides dresses and ornaments, they have also started to abandon their own identity markers called Tattoos. Traditionally all Tharu women should get Tattoos on their bodies but these days they are not willing to do so. However, the youngsters have started get Tattoos in their bodies in the name of fashion but not in the name of culture.

\section{Commercial Hospitality}

Culturally, Tharus have their own type of hospitality. In this context, it is very important to observe and know that whether they are maintaining original hospitality or not in the vicinity of tourist destination.

This study result shows that they have preserved and commercialized their traditional hospitality expecting something in return from the guests. Hence, they take their guests to their houses where guests are highly welcomed and praised with their local foods and drinks. In return some incentives are given by the guests. This makes the natives more ambitious and commercial. Regarding this $60 \%$ and above respondents, they have provided their consent about their traditional hospitality changing into commercial. It means that the original hospitality has been replaced by the commercial hospitality.

\section{Host - guest marital relationship:}

By the study it has been found that some naturalist and native boys' got married with the guests in the past. The reason behind the marriage was the economic benefit from the foreign partner. This shows that the Tharu boys were influenced by the ambitious of building good career in abroad. But it has been found that none of the Tharu girls got married with foreign boys.

\section{Cultural Impact}

The movements of domestic and international tourists influence the society and culture of host community. The Chitwan National Park is a major tourist destination among the others because of its cultural, biological diversity, natural beauty, and strong social behavior, religious feeling and traditional culture of the natives. The nature of human beings is imitating new things from others. Especially, the youngsters, who are highly curious to imitate new things without being well aware of the consequences. 
Therefore, it is found that due to the number of tourists the culture has been affected. Modernization, globalization and urbanization also contribute to the cultural changes. The following are the major area in which changes have been occurred in Tharu society.

\section{Physical products}

Physical products comprise cultural materials like art and crafts, and other constructive materials. Before the introduction of tourism in Sauraha, the Tharus were busy in their farming and whenever they were free they used to work in making different kind of materials such as Pira (Pirka), Vakari( grain storage), Chhatyer( Chhatri), Dhanna (placing the seeds of potato) etc. Previously, they used to concentrate on making things more qualitative. But after the introduction of tourism they have started to focus on producing things in large scale for business motives. Therefore, their goods have started to get more commercialized and factors like quality and originality have started to get ignored. They focus on goods which are mostly demanded by the guest. In short, they have diverted their mind from aesthetic materials to commercial aesthetical materials.

Similarly, the traditional architectural artifacts have been replaced by modern equipments such as pressure cooker, rice cooker and other new things are in most of the houses. The house painting and wall painting are made just for formality and only for the tourists. All these scenarios reveal that Tharu are keeping away from their traditional aesthetic values by adopting borrowed cultures. Before the introduction of tourism, houses of local peoples were made by mud, cow dung, straw with low height door and peeping window without any storey. But nowadays they have built concrete houses of multi stories.

\section{Dance}

Dance is an important aspect of the Tharu culture in Sauraha. They perform different type of dances like harvesting dance, Jhiri dance, holy dance (Damju dance), Thekada dance, peacock dance etc. Dancers perform the dance with their traditional dresses that show their uniformity. All these dances were part of their life and performed in different festivals and occasions. But nowadays, they perform the dance for the tourists, to attract them. It has been found that every evening group of male and female of Tharu peoples from different neighboring villages like Padampur, Patna come to perform their cultural dances. They get paid for dancing. This reveals that Tharu dances have totally become commercialized. Somewhere, they are practicing the modern songs with modern musical instruments. It is a matter of worry that traditional Tharu culture is being deteriorated rapidly and replaced by western music and culture.

\section{RESEARCH METHODOLOGY}

Observation and questionnaire method were used as data collection tools. This research has adopted descriptive research design. Descriptive in the sense that this research carefully tries to record all the observed events from the study area and describe fairly as possible.

\section{CONCLUSION}

Tourism is the world's fastest growing industry and samething happening in Nepal as well. Nepal has many more naturally and physically beautiful different heritages, which are famous all over the world. Hospitality, friendly people, numerous attractions, unique cultures are the main assent of tourist attractions in the country.

Cultural assimilation occurs when two cultures come in contact. The more technologically influential group gains supremacy while the latter society readily adopts the former. The same 
phenomenon has occurred in Sauraha, where the Host culture has been highly influenced and affected by the guest culture.

The finding of research shows that dramatic changes have been taken place due to the modernization, urbanization, and tourist activities. The cultural conflicts have been taking place when gross disparity between the affluence of tourists and poverty hidden people of the host region comes together. Thus in the process of development of tourism, weak sectors sometimes lose their moral values.

\section{BIBLIOGRAPHY}

A county studies. URL: "http://countrystudies.us/".

Bhattarai, Toyanath, (2006), Tourism Management, Min Bhawan, Kathmandu, Ishwori Books and Stationery,

Bohara, Bishnu Prasad, (2007), Tourism in Nepal: Problems and Prospects of Tourism in Salyan District, T.U.,

Brocher, chitwan Tourism Development committee (CTDC), Bharatpur, chitwan.

Cohen, E., (1984), the Sociology of Tourism: Approaches, Issues and Findings; Annual Review of Sociology, 10:373-392.

Eco-Tourism Management Plan in KMTNC supported Community Forests, Final Report, By: Centre for Social and Economic Studies, Kathmandu.

Godfrey, K and Clarke, J, (2000), The Tourism Development Handbook: A Practical Approach to Planning and Marketing.

Gunerathne, Arjun, (1999), "Modernizing Matwalis: Cast, class and status among the tharu of chitwan", in Herald (ed ),Nepal: tharu and terai Neighbors,

Himalayan times, (2003)

Kattel, Bishnu, (2006), Problem and Prospects of Tourism in Nepal: A Case Study of Sauraha, Chitwan, M.A,Dissertation submitted to Birendra Campus, T.U

KMTNC,(1996), RoyalChitwanNational Park after twenty Years: An Assessment of Values, Threats and Opportunities,

Kunwar, Ramesh Raj (2002); Anthropology of Tourism: A Case Study of Sauraha, Adroit Publishers,India

Kunwar, Ramesh Raj,(2006), Tourists and Tourism, Dillibazar, Kathmandu, InternationalSchool of Tourism and Management.

Mathieson, A - G. Wall, (1982), Tourism. Economic, Physical and Social Impacts; Longman Scientific \& Technical, Harlow, UK .

Ministry of Culture, Tourism and Civil Aviation. URL: "http://www.tourism.gov.np/".

MoCTCA, Nepal Tourism Statistics 2008, Ministry of Culture, Tourism and Civil Avation, HMG, Kathmandu.

Nepal Association of Rafting Agents. URL: "http://www.raftingassociation.org.np/".

Nepal Association of Tour and Travel Agents. URL: "http://www.nata.org.np/."

Nepal Tourism Board. Nepal Departing Visitors Survey 2008.

Nepal Tourism Board. Draft Master Plan. 2004.

Nepal Tourism Board. Nepal Tourism Performance in 2007.

Nepal Tourism Board. URL: "http://www.welcomenepal.com/".

Nepal's Experience Implementing Sustainable Tourism Development Models, Published By: Ministry of Culture, Tourism and Civil Aviation, UNDP/TRPAP, Kathmandu, 2007. 
Pizam, A - A. Milman - B. King (1994): The Perceptions of Tourism Employees and Their Families towards Tourism: A Cross-cultural Comparison; Tourism Management 15(1):53-61

Pradhanag,S.B, (1993), “ Tourist consumption Pattern and its Economic impact in Nepal”, Ph.D Dissertation, T.U

Price MF/Harrison D, (1996), Fragile Environments, Fragile Communities? An Introduction:People and Tourism in Fragile Environemnts, John Wley and Sons Ltd.

Responsible travel Nepal. URL: "http://www.responsibletravelnepal.com/".

Sharma, Pitamber,(2059), Paryatan Bikas le Garibi Ghatchha (in Nepali).Bikas, Year 10, vol 22,Atmanirvar Bikas Manch, Kathmancu (pp 4-8)

Sharma, Udaya Raj, (1991), Park-People Interaction In Royal chitwan National Park,Nepal, unpublished Ph.D. Dissertation submitted to faculty of the committee on wildlife and fisheries science, the University of Arizona.

United Nations environment programme world conservation monitoring centre

Upadhaya, Rudra Prasad, (B.S. 2065). Opportunity and Threats of Tourism Promotion in Chitwan, Paper presented in Chitwan Mahotsav.

Vyas, Ashok (n.d), Nepal Darshan, Gujrat (India): Kantalaxmi Publishers. 